\title{
The Environmental and Radiological Impacts in Abu Ghalaga Ilmenite Mine, South Eastern Desert, Egypt
}

\author{
Mahmoud, M. A. M. \\ Nuclear Materials Authority, P.O. 530, El Maadi, Cairo, Egypt \\ *Corresponding Author: Mahmoud, M. A. M, Nuclear Materials Authority, P.O. 530, El Maadi, Cairo, \\ Egypt

\begin{abstract}
Abu Ghalaga mine area is a part of the Arabian Nubian shield, south Eastern Desert, Egypt. It is composed of ilmenite-bearing rocks (Gabbroic rocks), older granitiods, volcanic and metavolcanic rocks. The studied area is characterized by low to moderately hills dissected by numerous of Wadies run towards the Red sea coast, with sometimes a flash floods risks.

The mining activities have been identified as one of the major pathways through which natural radionuclides are accumulated in the terrestrial environment. Exposure to excessive radiation can cause deleterious health hazards to the workers in the mine. Theradioactive concentrations of doze rate $\left(D . R . \mathrm{nSvh}^{-1}\right)$,Potassium $(K \%)$,equivalent uranium (eU ppm) and equivalent thorium (eTh ppm) were measured within the environment of Abu Ghalaga mine in order to estimate the radiological impacts. Field gammarayspectrometer (Rs-230)was a well calibrated NaI(Tl) detector to employ for these measurements. The Results show that the average activity concentrations of D.R., K, eU and eTh are 4.6, 0.32, $0.7 \& 0.86$ respectively for theilmenite lenses, 25.5, 2.2, $2.4 \& 5.5$ respectively for the gabbroic rocks, 45.7, 3.9, 4.0 \& 11.3 respectively for the older granitiods and 31.04,2.54, 3.15\& 9.44 respectively for the Wadi deposits.
\end{abstract}

The Radiological hazards calculated from the radioactive concentrations showed that the Abu Ghalaga mine area hasa little or no negative impacts on the environment as the radiological risks obtained are all lower than the permissible limits of Global average soil.

Keywords: Ilmenite, Abu Ghalaga, Gabrrioc rocks, Radiometric Measurements, Radiological Impact, Egypt

\section{INTRODUCTION}

The Arabian Nubian shield has been affected by a major transcurrent fault system known as the Najed shear zone (Stern, 1985). The Najed shear zone has dominant trend NW-SE and the displacement along which is mostly left lateral (Brown, and Coleman, 1972). The effect of Najed Shear zone extends to the central and south Eastern Desert of Egypt, and was responsible for the dismembering of the ophiolite sequences (Sultan, et al., 1988, 1990). Most of ultramafic rocks of Egypt belong to the "Alpine-type" variety that characterized the orogenic belts (Takla, and Nowier, 1980). The gabbroic rocks of Egypt were classified by Takla (1971) for the first time into older gabbros and younger gabbros based on the geological, ore-mineralogical and geochemical aspects. The older gabbros are being related to the ophiolitic rocks while the younger gabbros were considered to be post-orogenic continental intrusions(Takla, et al., 1981).

The natural radioactivity depends on geological environments, where uranium (U), thorium (Th) and potassium $(\mathrm{K})$ are the main radionuclides that contribute to the natural terrestrial radioactivity. Uranium and thorium decay series are less incompatible in accessory minerals such as apatite, zircon, monazite, sphene and allanite as well as essential minerals such as alkali feldspars. Thus the higher radiation levels are associated with some felsic plutonic and volcanic rocks such as granite, syenite, rhyolite and dacite which may be enriched with $U$ and Th-bearing accessory minerals (Roger and Adams, 1969; Smith, 1984; Finch and Murakami, 1999; Heikal, et al., 2016; Heikal and Top, 2017;Erkül, et al., 2016; El Afifi, et al., 2017).

The natural radioactivity from primordial origin is the vastdetected on the earth. Uranium (U) in nature is found as $\mathrm{U}^{238}$, one of the heaviest elements that exist mainly in the earth crust with activity 
The Environmental and Radiological impacts in Abu Ghalaga Ilmenite Mine, South Eastern Desert, Egypt

appearing in soil, in water and in some rocks(UNSCEAR, 1993). Uranium has been deposited by volcanic action, and occurs in different rock types from sedimentary to volcanics(HPS, 2011). Thorium $\left(\mathrm{Th}^{232}\right.$ ) occurs naturally in the earth's crust in combination with other minerals such as silica. The redistribution of radioactive minerals in soil rocks as well as in water is happening throughout the environment by wind, rain and geologic processes(ATSDR, 1999).

Ilmenite occurs in Egypt as a massive-type interlayer with gabbroic rocks at Abu Ghalaga mine and as a placer type in the black sands at the Mediterranean beach at Rosetta and Damietta.Abu Ghalaga mine is an existing mining operation located at the intersection of Wadi Abu Ghusun and Wadi Abu Ghalaga of the southern part of the Eastern Desert (Fig.1). The mine had been in operation for over 30 years ago and produces ilmenite ore.The aim of this paper torefers the environmental and radiological impacts on the Abu Ghalaga mine, SED, Egypt.

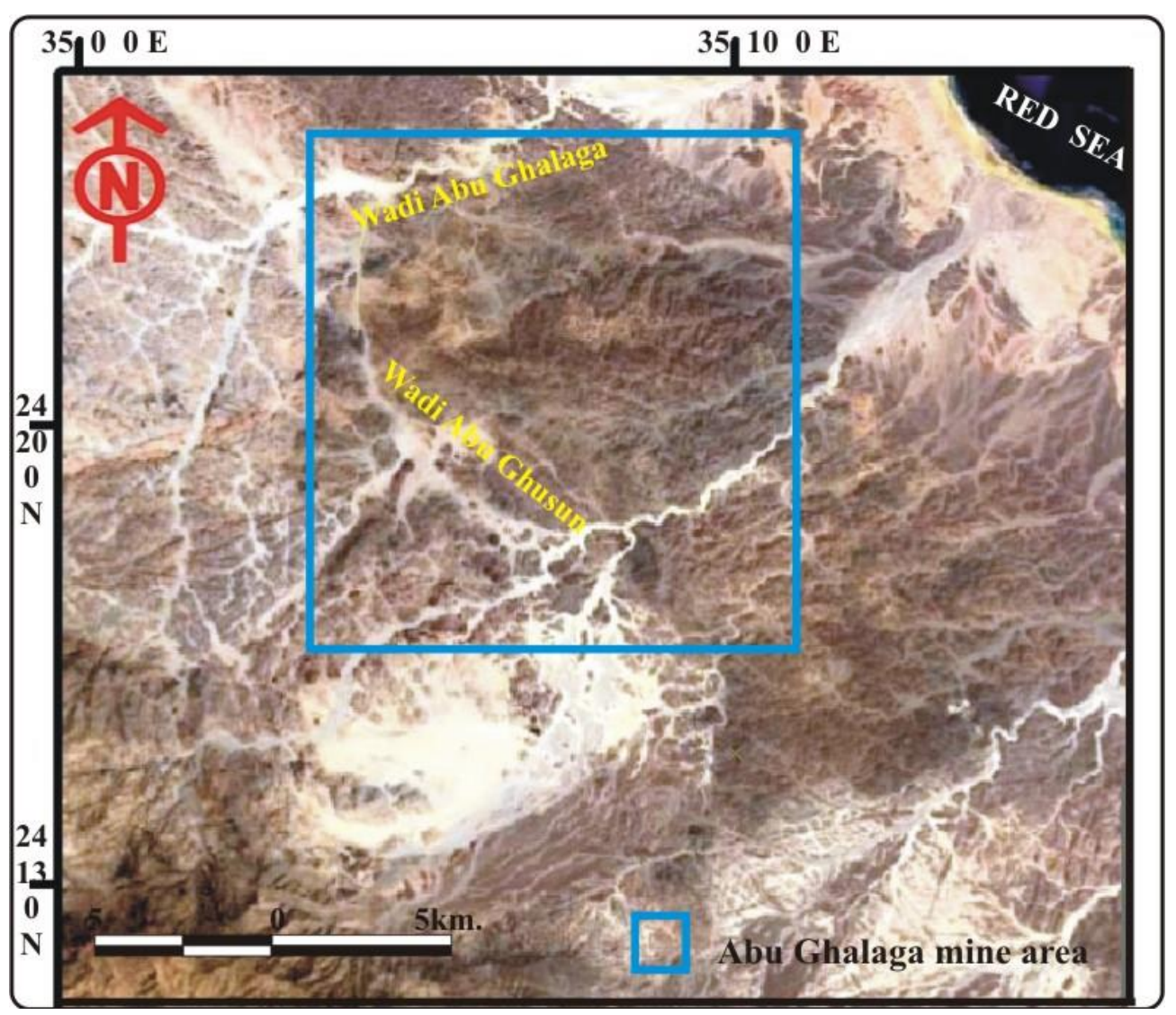

Fig1. Landsat photo showing Abu Ghalaga mine area and around it, SED, Egypt

\section{RESULTS AND DISCUSSION}

\subsection{Geology}

Abu Ghalaqa ilmenite mine lies about $18.0 \mathrm{~km}$ Southwest of Abu Ghusun on the Red Sea coast and about $105 \mathrm{~km}$ South of Marsa Alam city. The local geology of Abu Ghalaga ilmenite mine is described as alluvial deposits and Precambrian rocks. Geologic map was established for Abu Ghalaga area(Fig.2), where the rock unites from youngest to oldest are; Andesitic volcanic rocks, gabbroic rocks, older granitiods and metavolcanics.

The ilmenite-bearing rocks at Abu Ghalaga mine are represented by titaniferous gabbroic rocks, which occur as sheeted-like body with NW-SE and SE trend, and dips $\left(28^{\circ}-50^{\circ}\right)$ to the NE direction. They are bordered on the western side of the geologic map by hills of older granitiods, and by metavolcanic rocks of Gable Sarubi on the eastern side. The ilmenite masses occur as lenses (Fig. 3) having length ranging between $50 \mathrm{~m}$ to $300 \mathrm{~m}$, and width was ranging between 10 to $150 \mathrm{~m}$. Three field types of ilmenite ore are found in Abu Ghalaga mine as; black ore, red ore, and disseminated ore (Figs. 3\&4). Abu Ghalaga ilmenite mine is considered as a one of the old mines in the eastern Desert of Egypt, where the mining of the ilmenite ore is depends on the trenches and the shaft (Fig. 5). 
The Environmental and Radiological impacts in Abu Ghalaga Ilmenite Mine, South Eastern Desert, Egypt

The extracted ilmenite ore in Abu Ghalaga mine (Fig. 6) composed mainly of hematite, magnetite and ilmenite minerals forming up to $75 \%$ of the bulk of the ore. Magnetite and goethite rich bands were also found in the ilmenite-bearing rocks (gabbroic rocks). In the north and south of the Abu Ghalaga mine, the gabbroic rocks intruded in the metavolcanics and older granitiods.

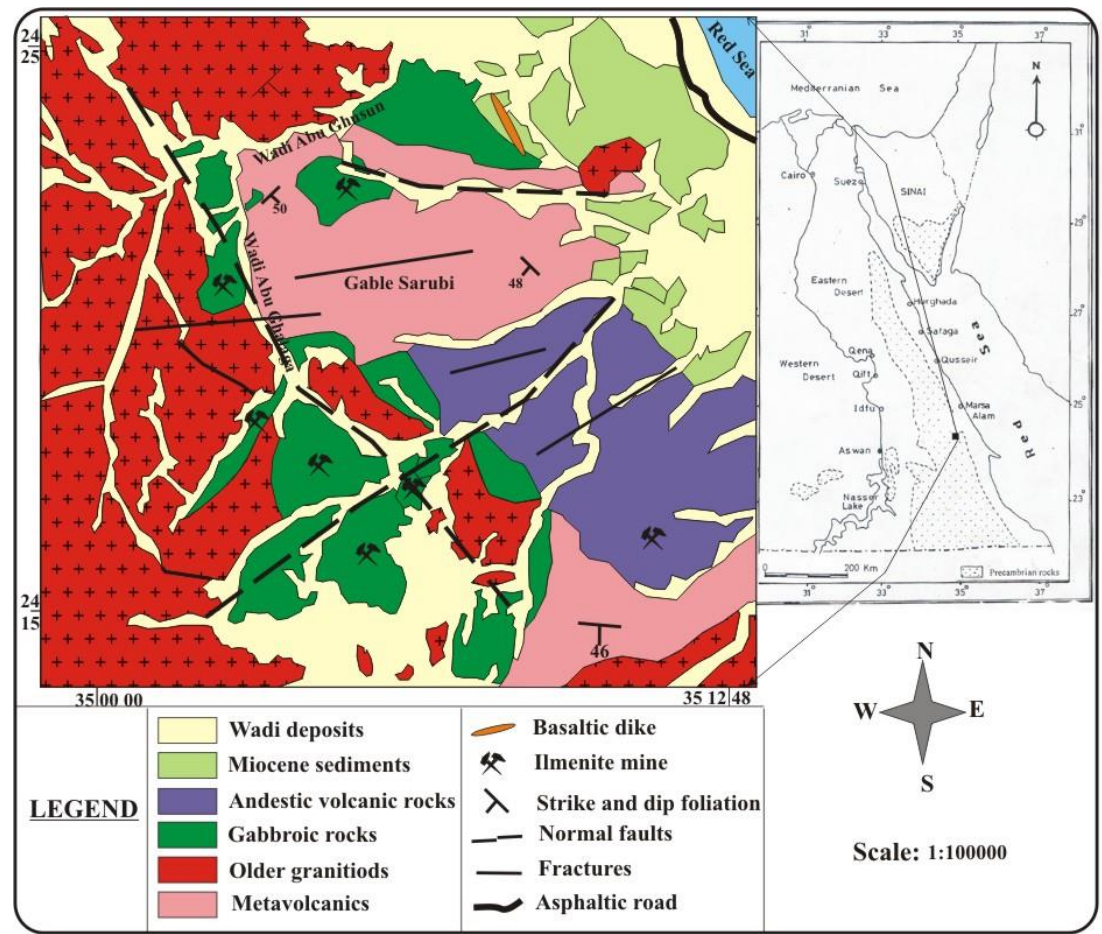

Fig2. Geologic map of Abu Ghalaga mine area, south Eastern Desert, Egypt(Modified after Conco)

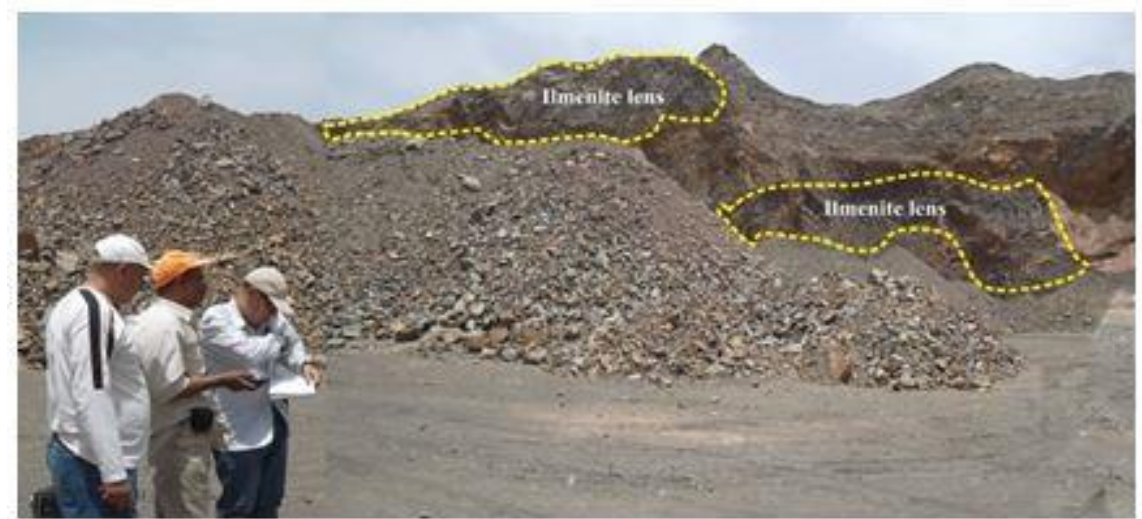

Fig3. Photograph showing the occurrence of the black type of the ilmenite ore as elongated lenses in Abu Ghalaga mine, SED, Egypt

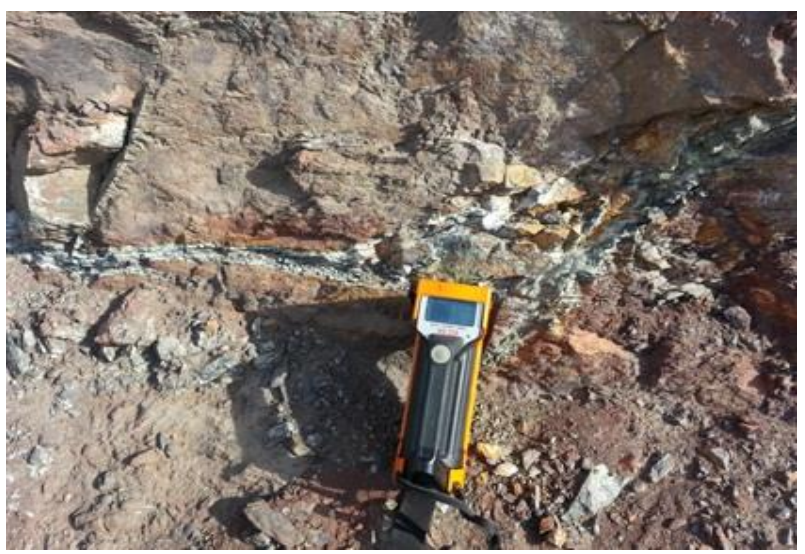

Fig4. Photograph showing the red type of the ilmenite ore in Abu Ghalaga mine, SED, Egypt 
The Environmental and Radiological impacts in Abu Ghalaga Ilmenite Mine, South Eastern Desert, Egypt

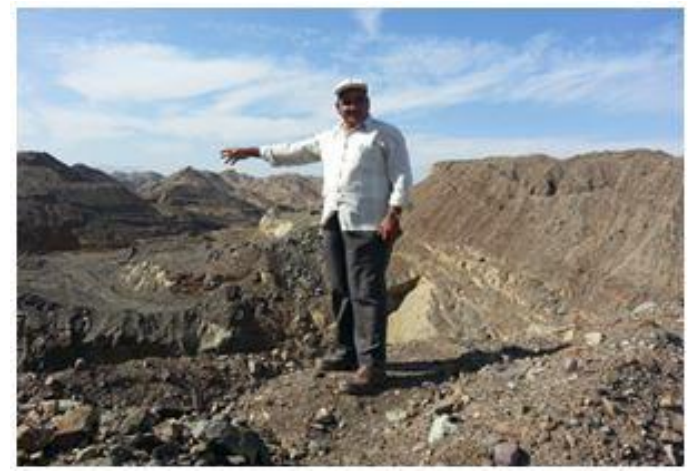

Fig5. Photograph showing the shafts and the trenches for mining ilmenite ore in Abu Ghalaga mine, SED, Egypt

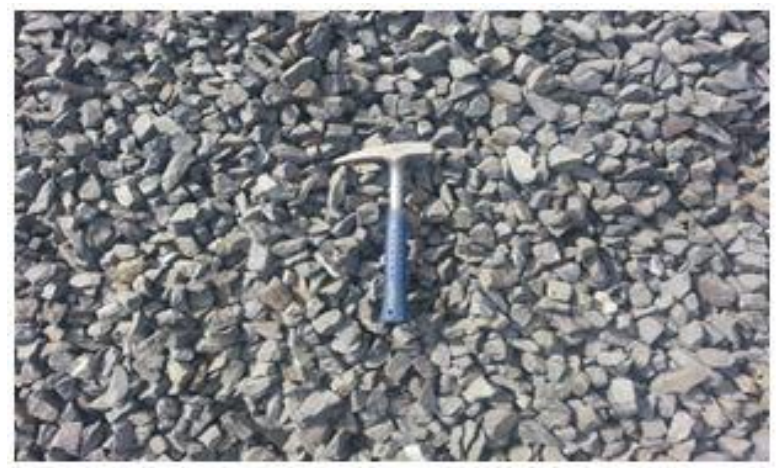

Fig6. Photograph showing the extracted ilmentie ore in Abu Ghalaga mine, SED, Egypt

Petrographically; Gabbroic rocks composed of plagioclase, clinopyroxene with minor amount of orthopyroxene and olivine. The opaque minerals are represented by ilmenite and pyrite. Chlorite and serpentineare found as secondary minerals. The gabbroic rocks are characterized by sub-ophtic texture as well as the parting and zoning phenomenon are very rare but considerable alteration is found in these rocks. Plagioclase crystals are subhedral to anhedral in shape, coarse-grained and have no compositional zoning. Plagioclase crystals are altered and have unregularly boundaries between other neighboring minerals (Figs. 7 and 9). Some mafic minerals and altered product have filled interstitial spaces among the plagioclase grains. Pyroxenes are medium-grained, subhedral to anhedral in shape and sometimes smaller grains of pyroxenes occur in clusters (Fig. 8). A few grains of pyroxenes are broken and occupyinterstitial spaces among other minerals. Olivine minerals are medium-grained, subhedral to anhedral in shape with irregular fractures and show high relief. Most of the olivine grains have been altered into serpentine and chlorite (Fig. 9).The disseminated type of ilmenite mineral is in the gabbroic rocks fills the interspaces of pyroxene andfeldspar minerals and may enclose them poikilitic texture(Fig.8). Altered pyrite grains are scattered in the ilmenite ore and they are confirmed by SEM (Fig. 10).

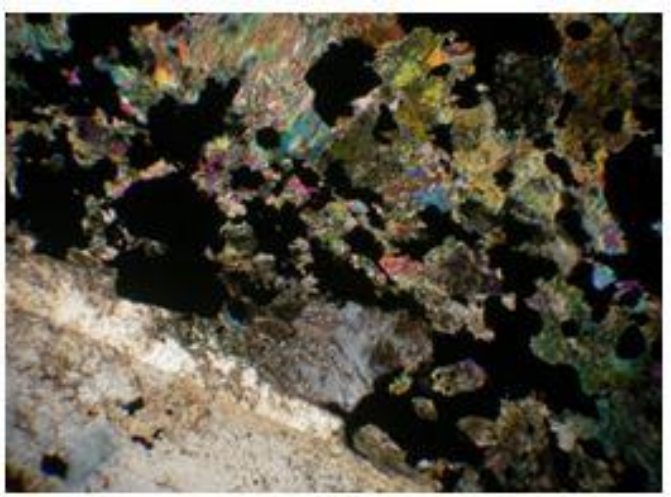

Fig7. Photomicrograph showing the plagioclase, ilmenite, pyrite, pyroxene and olivine minerals in gabbroic rocks at Abu Ghalaga mine.C.P.,X 10

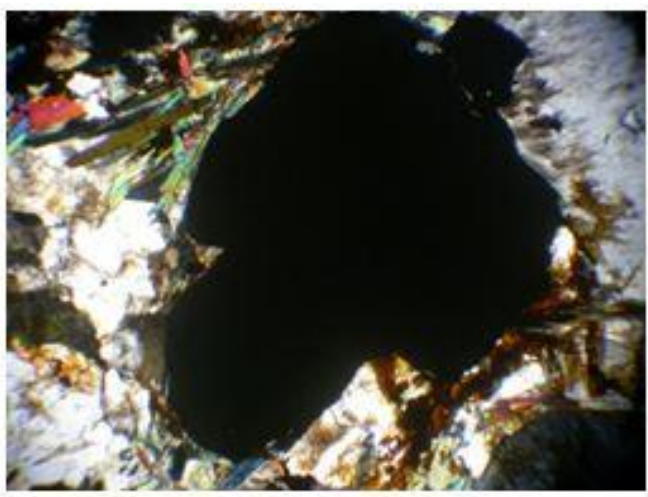

Fig8. Photomicrograph showing the pyrite crystal. Notice the plagioclase and mafic minerals in gabbroic rocks at Abu Ghalaga mine. C.P., X 20 
The Environmental and Radiological impacts in Abu Ghalaga Ilmenite Mine, South Eastern Desert, Egypt

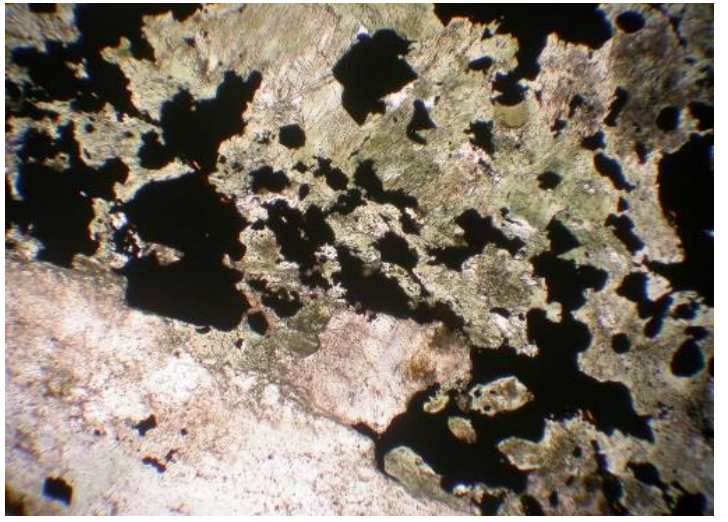

Fig9. Photomicrograph showing chlorite and serpentine minerals as the alteration products of mafic minerals. Notic the ilmenite and pyrite minerals (Black color) in gabbroic rocks at Abu Ghalaga mine, SED, Egypt. P.PL., X 20

\subsection{Geomorphology}

Abu Ghalaga area consists of a series of prominent hills and slight undulations with the highest point being at Gable Sarubi (468m). The granitoid rocks are strongly weathered forming low to moderate hills. On the other hand, the gabbroic rocks are more resistant to weathering and hence form relatively higher hills. The hills in the studied area have relatively steep slope angles and form prominent features in the landscape (Figs. $3 \& 5$ ). The majority of the area adjacent to the hills comprises undulating, broad expansive fluvial plains, becoming increasingly flat towards the East and the South of the area.

\subsection{Climate}

The climate of Abu Ghalaga area is one that experiences a distinct wet season and a distinct dry season, where rainfall is less than the evaporation. Little to no rain falls during the dry season, which leads to a moisture deficit when the vegetation must rely on soil water storage.

At the Abu Ghalaga area, the climate is that typical of the arid tropics being hot and moist during summer and dry in winter. The average rainfall is estimated to be around $2.3 \mathrm{~mm} / \mathrm{year}$. The wet season typically begins in October and ends in February, with the highest average monthly rainfall reading of $420 \mathrm{~mm}$ in August. The dry season, beginning in March and ending in September. The average rainfall during the dry season varies from a minimum of $7 \mathrm{~mm}$ in to a maximum of $99 \mathrm{~mm}$. The temperature is ranged from a mean $15^{\circ} \mathrm{C}$ at night to $33^{\circ} \mathrm{C}$ during day time in winter, and it is ranged from a mean $30^{\circ} \mathrm{C}$ at night to more than $45^{\circ} \mathrm{C}$ during day in summer. The relative humidity is ranged from $25-55 \%$, with higher humidity measured during the wet season and lower humidity measured in the dry season. (The former information are based on meteorological station of Ras Banas, which is the nearest meteorological station).

\subsection{Drainage Patterns}

Abu Ghalaga-Abu Ghusun area represents a part of the Red Sea drainage submegabasin. The final shaping of the drainage patterns is an outcome of the last fluvial periods, particularly the present dry valleys and their tributaries which were engraved during these fluvial periods(El Shazly, et al., 1991). The dry Wadies are filled with surficial deposits of sands, clays and gravels. The drainage patterns and boundaries of Wadi basins are shown in figure (11). The degree of uniformity of the drainage lines and their angles of juncture differ from one place to another. In the studied area, the common types of drainage patterns along the basement highland are coarse dendritic-subdendritic to trellis types and there are three separate drainage basins, which are described in the following:-

Wadi Abu Ghalaga basin is the fourth order and dense in its upstream part with variable angles of juncture. The pattern is dendritic to subdendritic in some parts and parallel to subparallel in the others. The trunk of Wadi Abu Ghalaga flows NE and is characterized by steep slope in the upstream of the main course and its large tributaries leading strongly vulnerable to torrential floods. 
The Environmental and Radiological impacts in Abu Ghalaga Ilmenite Mine, South Eastern Desert, Egypt

Wadi Ranga basin is a second order withmeanderingchannel andflows E-W towards the Red Sea. The basin mouth is crossed by a short segment of the Red Sea coastal road, which is moderately vulnerable to flooding.

Wadi Abu Ghusun basin is the fourth order and its drainage net is well developed, dense and has variable angles of juncture. The large channels are mostly arranged in parallel to subparallel patterns with dendritic to subdendritic tributaries. The main Wadi is trended N-S in upper part, NE-SW in middle part and W-E at the mouth. The main trunk of theWadi is narrow at the upperpart reflecting a high potential for flood hazards.

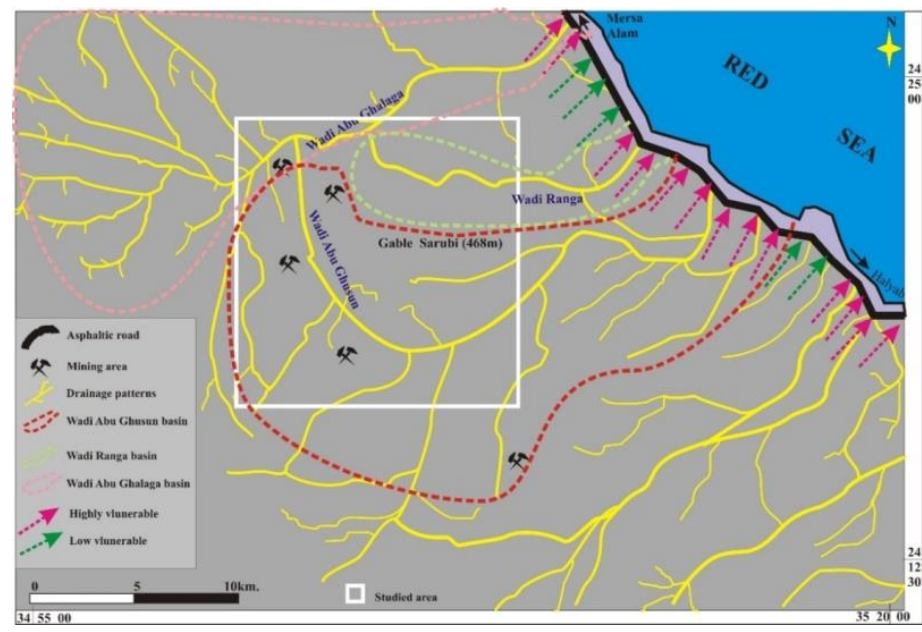

Fig11. Drainage patterns map showing the boundaries of the basins and Flash flood-vulnerable sites along the highway and the coastal zone in Abu Ghalaga area,SED, Egypt

\subsection{Radiation}

Ground spectrometric surveying using a portable gamma-ray spectrometer model Rs-230 (Fig.4)was carried out over the Abu Ghalaga mine area to measure the doze rate (D.RnSvh $\left.{ }^{-1}\right)$, equivalent uranium (eUppm), equivalent thorium (eThppm) and Potassium (K\%). Eighty stations (80) were covered the studied area, which distributed as; Twenty (20) station are measured for each type as; the ilmenite ore,gabbroic rocks, granitiod rocks, and Wadi deposits (Tables 1, 2, 3 \& 4).

The rocks units of Abu Ghalaga area contain secondary uranium minerals and minerals with elevated concentrations of radionuclides of the uranium and thorium decay chains such as monazite and zircon minerals. As the monazite and zircon minerals are progressively concentrated through mining and upgrading processes, the uranium and thorium concentrations of some process streams may be increase.

The enhanced radionuclide concentrations in Abu Ghalaga mine and processing operations will result in the radiation exposure of workers and, possibly, members of the public. Members of the public could additionally be exposed to potential dose rate from theair.

Table1. Radiometric measurements of ilmenite lenses in Abu Ghalaga mine area, south Eastern Desert, Egypt

\begin{tabular}{|c|c|c|c|c|c|c|c|c|c|}
\hline \multicolumn{10}{|c|}{ Ilmenite lenses } \\
\hline $\begin{array}{c}\text { Station } \\
\text { No. }\end{array}$ & $\begin{array}{c}\mathbf{D . R} \\
\left(\mathbf{n S v h}^{-\mathbf{1}}\right)\end{array}$ & $\mathbf{K \%}$ & $\begin{array}{c}\mathbf{e U} \\
(\mathbf{p p m})\end{array}$ & $\begin{array}{c}\mathbf{e T h} \\
(\mathbf{p p m})\end{array}$ & $\begin{array}{c}\text { Station } \\
\mathbf{N o .}\end{array}$ & $\begin{array}{c}\mathbf{D . R} \\
\left(\mathbf{n S v h}^{-1}\right)\end{array}$ & $\mathbf{K \%}$ & $\begin{array}{c}\mathbf{e U} \\
(\mathbf{p p m})\end{array}$ & $\begin{array}{c}\mathbf{e T h} \\
(\mathbf{p p m})\end{array}$ \\
\hline 1 & 4.4 & 0.1 & 0.7 & 0.2 & 11 & 8.5 & 1.2 & 0.7 & 2.1 \\
\hline 2 & 3.1 & 0.2 & 0.1 & 0.8 & 12 & 6.3 & 0.4 & 0.7 & 0.8 \\
\hline 3 & 5.8 & 0.1 & 0.8 & 0.3 & 13 & 5.4 & 0.1 & 0.6 & 0.9 \\
\hline 4 & 2.5 & 0.2 & 0.7 & 0.5 & 14 & 4.8 & 0.2 & 0.9 & 1.1 \\
\hline 5 & 2.2 & 0.1 & 0.5 & 0.4 & 15 & 3.9 & 0.1 & 0.4 & 0.7 \\
\hline 6 & 2.0 & 0.1 & 0.4 & 0.1 & 16 & 2.7 & 0.1 & 0.6 & 0.5 \\
\hline 7 & 4.9 & 0.2 & 0.9 & 1.2 & 17 & 5.6 & 0.3 & 0.7 & 0.8 \\
\hline 8 & 5.1 & 0.3 & 0.8 & 0.9 & 18 & 4.5 & 0.2 & 0.8 & 0.9 \\
\hline 9 & 6.2 & 0.5 & 0.9 & 1.7 & 19 & 3.5 & 0.3 & 1.0 & 0.7 \\
\hline 10 & 7.2 & 0.9 & 0.8 & 1.9 & 20 & 5.2 & 0.5 & 0.9 & 0.5 \\
\hline
\end{tabular}


The Environmental and Radiological impacts in Abu Ghalaga Ilmenite Mine, South Eastern Desert, Egypt

MIIN.

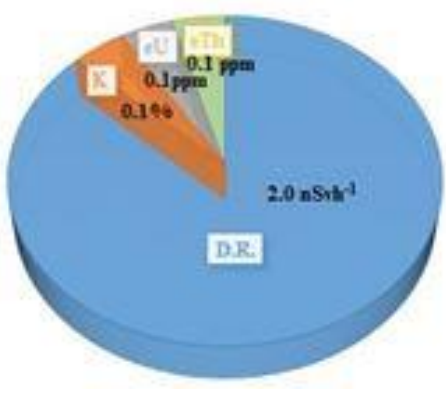

MAX.

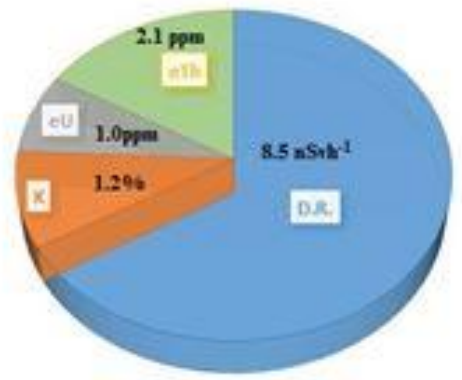

AVER.

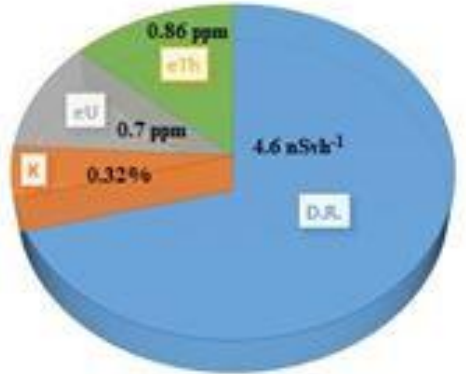

Fig12. Minimum (Min.), maximum (Max.)and average (Aver.)values of radiometric measurements in ilmenite lenses, at Abu Ghalaga mine area

Table2. Radiometric measurements of gabbroic rocks in Abu Ghalaga mine area, south Eastern Desert, SED, Egypt

\begin{tabular}{|c|c|c|c|c|c|c|c|c|c|}
\hline \multicolumn{10}{|c|}{ Gabbroic rocks } \\
\hline $\begin{array}{c}\text { Station } \\
\text { No. }\end{array}$ & $\begin{array}{c}\text { D.R } \\
\left(\mathbf{n S v h}^{-1}\right)\end{array}$ & K\% & $\begin{array}{c}\text { eU } \\
(\mathbf{p p m})\end{array}$ & $\begin{array}{c}\text { eTh } \\
\text { (ppm) }\end{array}$ & $\begin{array}{c}\text { Station } \\
\text { No. }\end{array}$ & $\begin{array}{c}\text { D.R } \\
\left(\mathbf{n S v h}^{-1}\right) \\
\end{array}$ & K\% & $\begin{array}{c}\mathbf{e U} \\
(\mathbf{p p m})\end{array}$ & $\begin{array}{c}\text { eTh } \\
\text { (ppm) }\end{array}$ \\
\hline 1 & 33.1 & 3.4 & 3 & 5 & 11 & 8.5 & 1.2 & 0.7 & 2.1 \\
\hline 2 & 20.6 & 2.9 & 2 & 4 & 12 & 6.3 & 0.4 & 0.7 & 0.8 \\
\hline 3 & 22.9 & 3.1 & 3 & 6 & 13 & 5.4 & 0.1 & 0.6 & 0.9 \\
\hline 4 & 35.7 & 2.5 & 2 & 5 & 14 & 4.8 & 0.2 & 0.9 & 1.1 \\
\hline 5 & 20.9 & 1.6 & 2 & 4 & 15 & 3.9 & 0.1 & 0.4 & 0.7 \\
\hline 6 & 23.7 & 1.9 & 3 & 5 & 16 & 2.7 & 0.1 & 0.6 & 0.5 \\
\hline 7 & 27.5 & 2.2 & 2 & 7 & 17 & 5.6 & 0.3 & 0.7 & 0.8 \\
\hline 8 & 30.9 & 2.6 & 3 & 8 & 18 & 4.5 & 0.2 & 0.8 & 0.9 \\
\hline 9 & 33.5 & 2.7 & 4 & 10 & 19 & 3.5 & 0.3 & 1.0 & 0.7 \\
\hline 10 & 21.6 & 1.7 & 2 & 5 & 20 & 5.2 & 0.5 & 0.9 & 0.5 \\
\hline
\end{tabular}

MIIN.

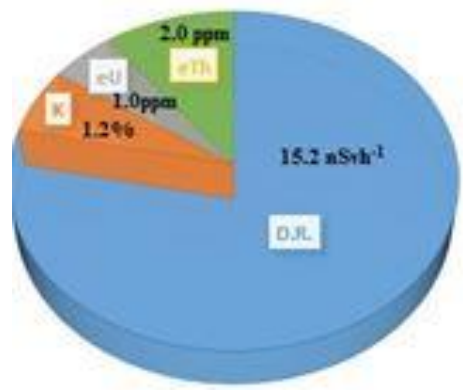

MAX.

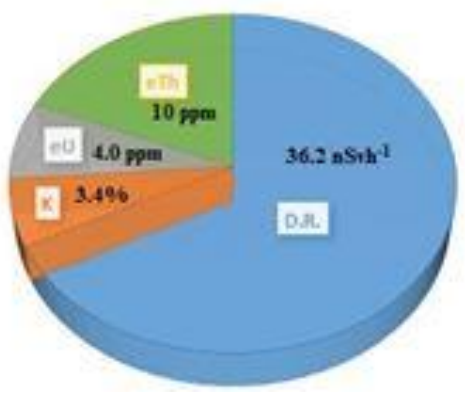

AVER.

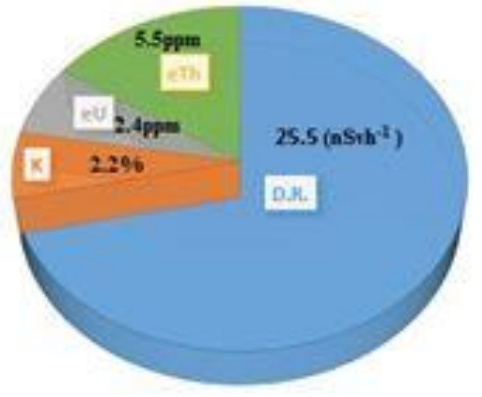

Fig13. Minimum (Min.), maximum (Max.)and average (Aver.)values of radiometric measurements in gabbroic rocks, at Abu Ghalaga mine area

Table3. Radiometric measurements of Older granitiods in Abu Ghalaga mine area, south Eastern Desert, Egypt

\begin{tabular}{|c|c|c|c|c|c|c|c|c|c|}
\hline \multicolumn{10}{|c|}{ Older granitiods } \\
\hline $\begin{array}{c}\text { Station } \\
\text { No. }\end{array}$ & $\left.\begin{array}{c}\mathbf{D . R} \\
(\mathbf{n S v h}\end{array} \mathbf{- 1}\right)$ & $\mathbf{K \%}$ & $\begin{array}{c}\mathbf{e U} \\
(\mathbf{p p m})\end{array}$ & $\begin{array}{c}\mathbf{e T h} \\
(\mathbf{p p m})\end{array}$ & $\begin{array}{c}\text { Station } \\
\mathbf{N o .}\end{array}$ & $\begin{array}{c}\mathbf{D . R} \\
\left(\mathbf{n S v h} \mathbf{- 1}^{-1}\right)\end{array}$ & $\mathbf{K \%}$ & $\begin{array}{c}\mathbf{e U} \\
(\mathbf{p p m})\end{array}$ & $\begin{array}{c}\mathbf{e T h} \\
(\mathbf{p p m})\end{array}$ \\
\hline 1 & 55.1 & 4.5 & 8 & 18 & 11 & 56.2 & 4.0 & 4 & 14 \\
\hline 2 & 46.6 & 3.8 & 5 & 15 & 12 & 57.8 & 3.0 & 3 & 10 \\
\hline 3 & 32.9 & 3.5 & 4 & 14 & 13 & 49.2 & 3.2 & 4 & 9 \\
\hline 4 & 35.9 & 2.3 & 5 & 9 & 14 & 48.6 & 3.5 & 3 & 9 \\
\hline 5 & 29.9 & 4.5 & 5 & 8 & 15 & 45.9 & 5.0 & 3 & 11 \\
\hline 6 & 36.7 & 4.1 & 6 & 7 & 16 & 46.7 & 4.1 & 4 & 9 \\
\hline 7 & 37.5 & 2.7 & 5 & 8 & 17 & 55.2 & 3.8 & 3 & 11 \\
\hline 8 & 39.9 & 3.0 & 4 & 11 & 18 & 41.8 & 4.0 & 4 & 17 \\
\hline 9 & 43.5 & 4.6 & 2 & 7 & 19 & 44.5 & 5.3 & 3 & 15 \\
\hline 10 & 51.6 & 4.4 & 3 & 11 & 20 & 39.7 & 4.3 & 2 & 12 \\
\hline
\end{tabular}


The Environmental and Radiological impacts in Abu Ghalaga Ilmenite Mine, South Eastern Desert, Egypt
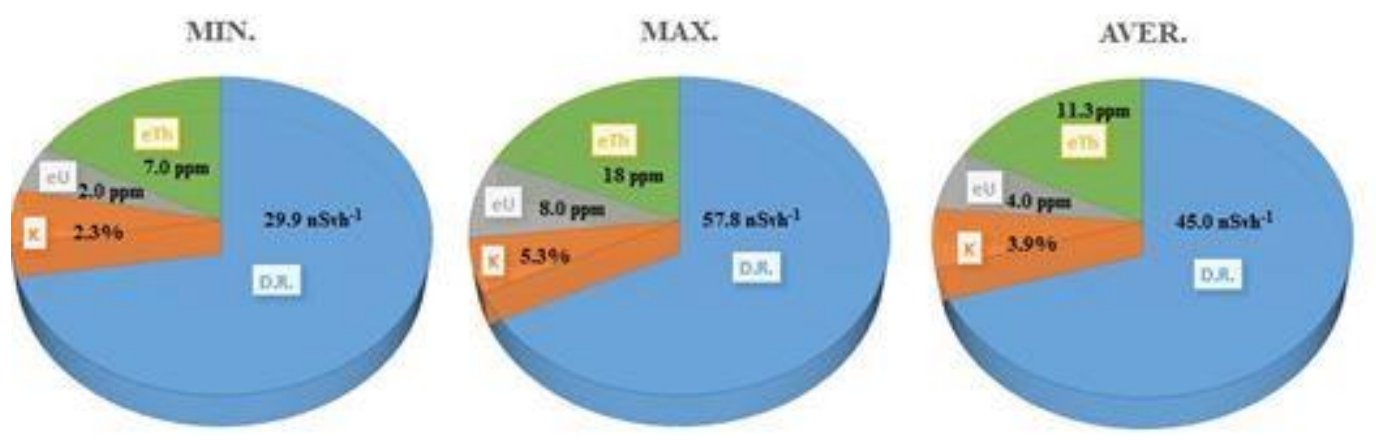

Fig14. Minimum (Min.), maximum (Max.)and average (Aver.)values of radiometric measurements older granitiods, at Abu Ghalaga mine area

Table4. Radiometric measurements of Wadi deposits in Abu Ghalaga mine area, south Eastern Desert, Egypt

\begin{tabular}{|c|c|c|c|c|c|c|c|c|c|}
\hline \multicolumn{9}{|c|}{ Wadi deposits } \\
\hline $\begin{array}{c}\text { Station } \\
\text { No. }\end{array}$ & $\begin{array}{c}\mathbf{D . R} \\
\left(\mathbf{n S v h} \mathbf{- 1}^{-1}\right)\end{array}$ & $\mathbf{K \%}$ & $\begin{array}{c}\mathbf{e U} \\
(\mathbf{p p m})\end{array}$ & $\begin{array}{c}\mathbf{e T h} \\
(\mathbf{p p m})\end{array}$ & $\begin{array}{c}\text { Station } \\
\mathbf{N o .}\end{array}$ & $\begin{array}{c}\mathbf{D . R} \\
\left(\mathbf{n S v h}^{-\mathbf{1}}\right)\end{array}$ & $\mathbf{K \%}$ & $\begin{array}{c}\mathbf{e U} \\
(\mathbf{p p m})\end{array}$ & $\begin{array}{c}\mathbf{e T h} \\
(\mathbf{p p m})\end{array}$ \\
\hline 1 & 51.2 & 4.5 & 3.0 & 11 & 11 & 25.0 & 2.4 & 3.4 & 9.2 \\
\hline 2 & 31.2 & 3.1 & 3.0 & 6 & 12 & 40.0 & 2.5 & 2.5 & 10.1 \\
\hline 3 & 24.0 & 2.6 & 2.6 & 10 & 13 & 50.0 & 1.9 & 3.1 & 9.5 \\
\hline 4 & 18.2 & 3.1 & 3.0 & 9 & 14 & 36.1 & 1.2 & 3.0 & 11 \\
\hline 5 & 18.0 & 2.2 & 3.8 & 8 & 15 & 50.0 & 2.2 & 3.5 & 9.6 \\
\hline 6 & 11.0 & 2.1 & 3.5 & 10 & 16 & 45.0 & 2.1 & 3.0 & 8.9 \\
\hline 7 & 17.0 & 2.0 & 3.2 & 9 & 17 & 35.0 & 3.0 & 3.8 & 9.7 \\
\hline 8 & 22.0 & 3.0 & 3.1 & 11 & 18 & 50.0 & 2.4 & 3.7 & 7.9 \\
\hline 9 & 23.0 & 2.4 & 2.5 & 10.3 & 19 & 20.0 & 3.1 & 3.5 & 10.2 \\
\hline 10 & 33.0 & 2.1 & 3.0 & 8.5 & 20 & 21.0 & 2.9 & 2.8 & 9.9 \\
\hline
\end{tabular}
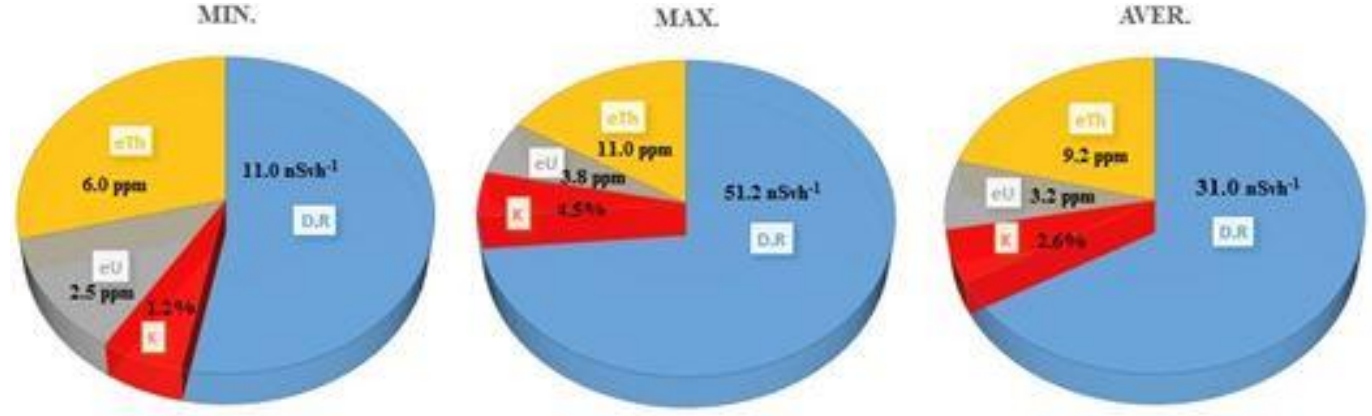

Fig15.Minimum (Min.), maximum (Max.)and average (Aver.)values of radiometric measurements in Wadi deposits, at Abu Ghalaga mine area, SED, Egypt

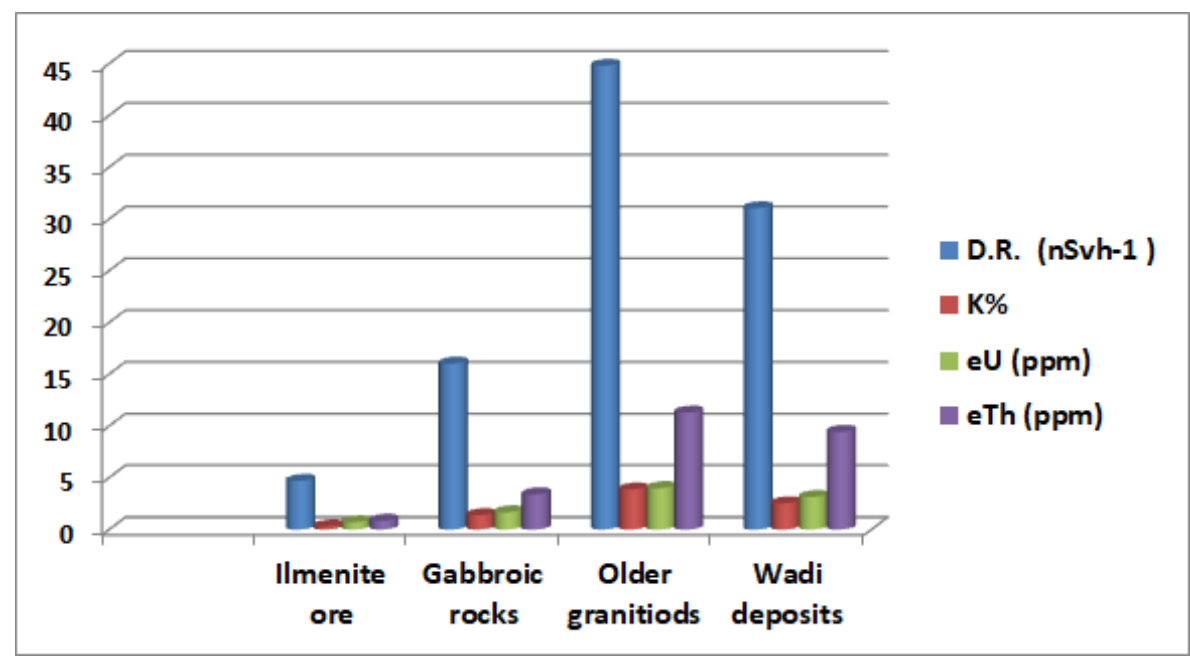

Fig16. Bar diagram illustrated the average content of D.R., $K, e U$ and $e$ Th in different rock units at Abu Ghalaga mine area,SED, Egypt 
The Environmental and Radiological impacts in Abu Ghalaga Ilmenite Mine, South Eastern Desert, Egypt

From the former tables(1-4)and figures(12-15), the radiometric measurements in the different rock units at Abu Ghalaga mine area are;

-The ilmenite lenses have average contents of D.R., K, eU and eTh as $4.6 \mathrm{nSvh}^{-1}, 0.32 \%, 0.7 \mathrm{ppm} \&$ $0.86 \mathrm{ppm}$ respectively.

-The gabbroic rocks have average contents of D.R. K, eU and eTh as $25.5 \mathrm{nSvh}^{-1}, 2.2 \%, 2.4 \mathrm{ppm} \&$ 5.5 ppm respectively.

-The older granitiods have average contents of D.R., K, eU and eTh as $45.0 \mathrm{nSvh}^{-1}, 3.9 \%, 4.0 \mathrm{ppm} \&$ $11.3 \mathrm{ppm}$ respectively.

-The Wadi deposits have average contents of D.R., K, eU and eTh as $31.0 \mathrm{nSvh}^{-1}, 2.6 \%, 3.2 \mathrm{ppm}$ $\& 9.2$ ppm respectively.

-Figure (16) illustrated that the older granitiods possess the highest values of D.R., K, eU and eTh, while the ilmenite ore are possess the lowest values of D.R., K, eU and eTh.

\section{CONCLUSION}

* At Abu Ghalaga mine area, the rock unites from youngest to oldest are; Andesitic volcanic rocks, gabbroic rocks, older granitiods and metavolcanics.

* The ilmenite-bearing rocks at Abu Ghalaga mine are represented by titaniferous gabbroic rocks,

* Abu Ghalaga ilmenite mine is considered as a one of the old mines in the eastern Desert of Egypt, where the mining of the ilmenite ore is depends on the trenches and the shaft.

* Abu Ghalaga area consists of a series of prominent hills and slight undulations with the highest point being at Gable Sarubi.

* At the Abu Ghalaga area, the climate is that typical of the arid tropics being hot and moist during summer and dry in winter.

* The main courses and its large tributaries of the large Wadies passing Abu Ghalaga mine area leading medium to strongly vulnerable to torrential floods.

* The information from the radiation investigation currently indicates that there are no specific measures required at closure to limit potential radiation impacts.

* All doses (D.R) calculated for Abu Ghalaga mine area are below the annual dose limit of permissible level $(59 \mathrm{nGy} / \mathrm{h})$ (UNSCEAR, 2000), while the average values of eU and eTh are less than Clark values (Clarke value for $e U=4 \mathrm{ppm}$ and for $e T h=18-20 \mathrm{ppm}$ ) (Clarke, et al., 1966).

\section{REFERENCES}

Agency for Toxic Substances and Disease Registry (ATSDR), 1999: Toxicological profile for thorium. Atlanta, GA: U.S. Department of Health and Human Services, Public Health Service; 1999. p.1999.

Brown, G. F. and Coleman, R. G., 1972: The tectonic framework of the Arabian Peninsula. 24 ${ }^{\text {th }}$. Int. Geol. Congr. Montereal, v.3, p. 300-305.

Clarke, SPJ., Peterman, ZE., Heier, KS., 1966: "Abundances in uranium, thorium and potassium. In: Handbook of physical constants", vol. 97. Geological Society of America Memoirs, New York, pp 521541.

El Afifi, E. M., Shahr El-Din, A. M., Aglan, R. F. E. H., Borai, E. H. and Abo-Aly, M. M., 2017: Baseline evaluation for natural radioactivity level and radiological hazardous parameters associated with processing of high grade Monazite. Regulatory Toxicology and Pharmacology 89, 215-223.

Erkül, S. T., Ozmen, S. F., Erkül, F. and Boztosun, I., 2016: Comparison between natural radioactivity levels and geochemistry of some granitoids in western Turkey. Turkish J Earth Sci., 25, 242-255.

El Shazly, E. M., Abdel Hady, M. A. and El-Rakaiby, M. L., 1991:Drainage megabasins in Egypt. Bull. Soc. Geogr. d, Egypt, Tome, LXIV. pp. 45-58.

Finch, R.and Murakami, T., 1999: Systematics and paragenesis of uranium minerals. In: Burns, P.C. and Finch,R., (Eds.), Uranium: Mineralogy, Geochemistry and the Environment. Rev. Mineral. 38, 91-179. 
The Environmental and Radiological impacts in Abu Ghalaga Ilmenite Mine, South Eastern Desert, Egypt

Health Physics Society (HPS), 2011: A citizen's guide to uranium, Health Physics Society Fact Sheet, February; 2011.

Heikal, M. Th. S., Mahmoud, K. R., El Sobky, T. and Top, G., 2016: Toward Assessment the High Gamma Dose Levels and Relevant HumanHealth Impactsfrom Precambrian Granites, Na'wah Area, Yemen Republic. Inter. J. Env. \& Water, 5/3, pp. 1-12.

Heikal, M.Th. S. and Top, G., 2017:Assessment of Radioactivity Levels and Potential, and Radiation Hazards Health of Madsus Granites and Associated Dikes Nearby and AroundRuwisat Village, South Sinai, Egypt. Journal of African Earth Sciences. Accepted.

Roger, J. J. W. and Adams, J. A. S., 1969: Uranium and thorium. In: Wedepohl, K.H. (Ed.), Handbook of Geochemistry, vol. 11/13. Springer, Berlin.

Smith, Jr., D. K., 1984: Uranium mineralogy. In: De Vivo, B., Ippolito, F., Capaldi, G. and Simpson, P.R. (Eds.), Uranium Geochemistry, Mineralogy, Geology, Exploration and Resources. The Institution of Mining and Metallurgy, pp. 43-88.

Stern, R. J., 1985: The Najed fault system, Saudi Arabia and Egypt: A late Precambrian rift-related transform system. Tectonics, v. 4. p. 497-511.

Sultan, M., Arvidson, R.E., Duncan, I. J., Stern, R. J. and El Kaliuoby, B., 1988: Extension of the Najed shear system from Saudi Arabia to the Central Eastern Desert of Egypt, based on integrated field and Landsat observations. Tectonics, v. 7, p. 1291-1306.

Sultan, M., Chamberlain, K. R., Brwring, S. A., Arvidson, R.E., Abu Zied, H. T. and El Kaliuoby, B., 1990: Geochronologic and isotopic evidence for involvement of Pre-Pan-African crust in the Nubian Shield, Egypt. Geology, v.18, p. 761-764.

Takla, M. A., 1971: Ore mineralogical and geochemical studies of some basic and associating ultrabasic igneous rocks. Eastern Desert. Egypt. Ph.D. thesis, Cairo Univ., Egypt.

Takla, M. A., Basta, E. Z. and Fauzi, E., 1981: Characterization of the older and Younger gabbros of Egypt. Delta. J. Sci. 279-314.

Takla, M. A., and Nowier, A, M., 1980: Mineralogy and mineral chemistry of the ultramafic mass of ElRubshi, E. D., Egypt. Neves Jahrb. Min. Abh., V.140/1, pp.17-28.

United Nations Scientific Committee on the Effects of Atomic Radiation(UNSCEAR), 1993: Sources and effects of ionizing radiation: Report to the General Assembly,with Scientific Annexes. United Nations, ISBN 92-1-142200-0; 1993.

United Nations Scientific Committee (UNSCEAR), 2000:on the Effects of Atomic Radiation, Sources and effects of ionizing radiation. Report V. 1 to General Assembly, with Scientific Annexes (NY).

Citation: Mahmoud, M. A. M., (2021) "'The Environmental and Radiological impacts in Abu Ghalaga Ilmenite Mine, South Eastern Desert, Egypt”, International Journal of Mining Science (IJMS), 7(1), pp. 1019. DOI: http://doi. org/10.20431/2454-9460.0701002

Copyright: (C) 2021 Mahmoud, M. A. M. This is an open-access article distributed under the terms of the Creative Commons Attribution License, which permits unrestricted use, distribution, and reproduction in any medium, provided the original author and source are credited. 